Ćalić, M., \& Đurđanović, M. (2020). Family and its role in the cultivation and preservation of traditional folk music at junior primary school age, International Journal of Cognitive Research in Science, Engineering and Education (IJCRSEE), 8(3), $103-112$.

Original scientific paper

UDK:

Received: November, 18.2020

Revised: December, 04.2020.

Accepted: December, 07.2020.

doi: 10.23947/2334-8496-2020-8-3-103-112

\title{
Family and Its Role in the Cultivation and Preservation of Traditional Folk Music at Junior Primary School Age
}

\author{
Maja Ćalićt ${ }^{*}$, Miomira Đurđanović2
}

\author{
${ }^{1}$ Faculty of Pedagogy in Užice, University of Kragujevac, Serbia, e-mail: maja.zlatibor@gmail.com \\ ${ }^{2}$ Faculty of Arts in Niš, Department of Music Art, University of Niš, Serbia, e-mail: miomira.djurdjanovic@gmail.com
}

\begin{abstract}
The cultivation of folk tradition begins in the family, and continues in a systematic and organized way in school as a certainly important task in the education and upbringing of children of junior primary school age. Factors contributing to the realization of this task include: a) school; b) family, and c) other out-of-school factors. Starting from the fact that the cooperation between one's family and school should be based on partnership, and that learning about traditional folk music requires coordinated action, authors organized a survey aimed at: 1) examining the extent to which the cultivation of musical tradition within the family is reflected on the learning and adoption of related content in music education classes at junior primary school age; 2) determining the extent to which traditional folk music is cultivated in the family by listening to and playing such music; 3 ) examining the role of family in the process of introducing students to traditional folk music at junior primary school age with regard to other in-school and out-of-school factors. The authors have concluded, teachers believe that cultivating traditional folk music in one's family is reflected in the form of recognition and improved student motivation for learning content, related to traditional folk music. Students believe that the activity of listening to folk music within family is an insufficiently utilized resource. The survey results confirm the hypothesis that the role of family should be significantly encouraged in relation to other out-of school factors.
\end{abstract}

Keywords: traditional folk music, music education, family.

\section{Introduction}

The learning and development of each individual begins within the family. Parents are the first educators and teachers of their children, therefore children acquire their first knowledge, skills and habits in the family. Preschool institutions and school join in the process later, but the influence of one's family never disappears.

Modern family "is a product of historical trends in which elements of the traditional and the modern are intertwined" (Zuković, 2012a, 16). It functions even in turbulent times that generate uncertainty. As the society has changed, so has family, however, the way it operates, family relations and family values have remained permanent and unchangeable. Regardless of its faults, family environment is perceived as a place where one will always find security, support and protection. The current social context and the generally accepted value system define the quality of family life in the broadest sense, and thus impact family functioning (Zuković, 2012a).

It should be noted that functional families are cohesive, stable, and their members cooperate frequently and productively. Such families are capable of facing and overcoming problems in a constructive way. The analysis of professional literature related to family functionality (DeFrain, 1999; Olson, 2000; Krysan et al., 1990; as cited in: Zuković, 2012a, 102) shows that experts' are justified in their opinion that further research should be focused on successful families which could provide "insights on how family transfers positive values and encourages one to develop functional behavioral patterns" (Zuković, 2012a, 102).

Results of the survey Happiness and Families with Children in Serbia conducted by the Public Policy Research Center for UNICEF show that family habits, family functioning and the social ties between its members play a significant role in the lives of individuals (Milanović and Andjelković, 2013).

Unique family values are reflected in the transfer of its value system onto a child. A child lays the foundations of the esthetic, moral, value and every other system as part of a family. Family forms one's attitude toward learning, education, knowledge and values. Our paper aims at drawing attention

"Corresponding author: maja.zlatibor@gmail.com 

primary school age, International Journal of Cognitive Research in Science, Engineering and Education (IJCRSEE), 8(3), 103-112.

to an important role of family - transmission and building of values that arise from our musical tradition. Through musical tradition, a child is introduced to the culture and history of his/her people, but also to the "history of mankind, because characters and events portrayed in traditional music also possess an element of universality, i.e. timelessness" (Pavlović and Cicović Sarajlić, 2013, 276). Given the fact that "children's folklore has witnessed childhood through countless ages and the spiritual maturation of mankind" (Ljubinković, 1976, 57), the role of family is that of an intermediary of sorts between individuals and the values characteristic of a certain society, then and now. Based on the knowledge that parents possess a complete value system, they will serve as a model for identification which translates its beliefs into "systems of norms and customs, expressing them in an understandable language and linking them to specific child's behavior" (Manić, 2016, 5).

Family plays a significant role in musical development of children (Bogunović, 2008; Radoš, 2010).

With the birth of a child, the first contact and the first perception of music in one's native language occurs within the family, including: spontaneous singings (lullabies, jingles, nonsense verse, counting rhymes, amusements, etc.), listening to and playing music on different media, and body movement (clapping, tapping, rocking, swaying, rattling, etc.), all of which stimulates and develops children's sense of melody and rhythmic pulse, as well as tempo (Nikšić, 2016, 18).

Research in the field of musicolinguistics suggests that the musical experience of children acquired primarily within the family prior to starting school, and "authentically preserved" in our long-term memory" has invaluable importance in the learning of new music content (Levitin, 2011, 184).

\section{Family environment and Traditional Folk Music}

These first musical experiences a child acquires and develops within the family contribute to the development of a generally positive attitude toward music and playing instruments, which greatly and directly impacts "the formation of one's musical taste and preferences" (Radoš, 2010, 124).

Children's attitude toward music greatly depends on their family, and the things it offers as a family model of behavior. If a family nurtures a positive relationship toward traditional folk music, it is likely that a child will also build a personal relationship with this music genre. In contrast, if children are left to their own devices when it comes to the formation of musical taste, it is likely that commercial music, as the most dominant and accessible at the moment, will shape their musical taste to a great extent (Nešic et al, 2006). One of potential solutions is to design and place a certain type of auditory performance containing elements of traditional folk music in every national environment. We can make such content more relatable and more familiar to children by repeating certain patterns based on which they should gain a certain musical experience. By enriching and expanding the children's auditory experience, they will form their musical taste with an inherent affection toward the musical tradition of their people. Of course, in addition to traditional folk music, children should be introduced to other forms of traditional and original music, both from their own, and other countries as well. Nešić reminds us that "accepting the music of other nations and other historical periods, and understanding it (universalization of musical inclinations) doesn't damage or threaten one's affection for their own traditional music, just as learning foreign languages doesn't make one forget their mother tongue" (Nešić, 2003, 232).

Čokorilo (2013) points out that family still successfully resists modern challenges thanks to traditional patterns, and represents one's intimate and very significant emotional community which helps preserve traditional values. It is, therefore, important that family should lay strong foundations for the preservation of tradition, language, origin and culture of one's nation in contrast to other nations, which could help develop sensitivity toward musical values and familiarize people not just with their own musical tradition, but the tradition of other nations as well. Thus, family may help communities which have undergone significant cultural changes in the global age to strengthen their national values and preserve their tradition (Deletić, 2013).

On the other hand, it is a fact that family is nowadays faced with serious challenges, media influence, globalization, social changes, and that the pressure of these changes has left family exposed to various influences and threats, fighting to preserve its identity and reconcile modernity and tradition (Zuković, 2009). Every individual is increasingly influenced by the media, and the environment that insists on commercial content and neglects traditional folk music. Learning about one's musical tradition primarily depends on the experience children acquire in their family, but also on the parents' relationship toward it, which is why it is important, as stated by Grandić (2007), to rely on the principles of coordinated action between all educational factors. Thus, by simultaneous action of teachers and the family toward children, and by introducing them to a wide range of domestic and foreign, original and traditional compositions, we will ensure further development of their musical taste, and shape their cultural identity (Vidulin and 
Ćalić, M., \& Đurđanović, M. (2020). Family and its role in the cultivation and preservation of traditional folk music at junior primary school age, International Journal of Cognitive Research in Science, Engineering and Education (IJCRSEE), 8(3), $103-112$.

Martinović, 2015).

Ethnomusicologists remind us that "children's songs (lullabies, jingles and nonsense verse) are slowly disappearing" (Fracile, 1987, 68), and the reason for this lies in the fact that parents no longer sing songs to their children, but play music on different media. In addition, seeing the media as a very influential factor, ethnomusicologist Dević explains that in the age of "very aggressive media domination over our traditional folk music, we have no other alternative but, just as we speak in our native language, to continue to sing our songs, passing on our musical and poetic heritage orally to our sons and daughters" (Dević, $2001,14)$. The role of family is to build a positive attitude toward traditional music from an early age, counterbalancing other circumstances and content present in the media. In this regard, Zuković (2012a) believes that "a healthy and functional family is one that can grow and develop despite the challenges and obstacles it encounters. It always strives to expand its experience, and solves problems through family rules and values. Its strengths include love, positive emotion, support, tolerance and compromise" (Zuković, 2012a, 74).

From the aspect of ethnomusicology, folk art has always had a pronounced social function in the historical and cultural development of Serbian people, and a special place in the development of family. It is a well-known fact when certain songs are to be sung, why they are to be sung, how certain folk dances are to be performed, with what intention and purpose. It is no coincidence that in the past, traditional folk singing was the most common form of musical performance in this part of the world, just as ethnomusicologist Golemović reminds us - "there was no person living in rural areas who wouldn't sing, whether the occasion was everyday or ceremonious" (Golemović, 1998, 7).

In order to develop moral education, singing and listening to traditional folk songs were used to nurture patriotism and identification with one's nation. The content of traditional folk song reflects moral feelings, including honor, pride, dignity, responsibility, awareness of the necessity of work, respect for truth, and respect of other nations and cultures (Pavlović, 2013). Family is the main drive and initiator responsible for the moral behavior and actions of children both in the closest and a broader environment. In addition to listening to and performing traditional music, attending concerts and other performances and events of domestic and foreign artists that cultivate the spirit of musical tradition significantly enriches musical experience of young generations (Ćalić and Đurđanović, 2016). Moreover, school as the main representative of formal education since the beginnings of civilized society should provide support for the family, and utilize its mechanisms and instruments so as to realize the aspiration to preserve traditional folk music (Kostović, 2005).

There are many ways in which family can help to familiarize children with their musical tradition. Some of them include:

- establishing a partnership between family and school, and exchanging experiences referring to musical tradition;

- cultivating the habit of listening to traditional music within the family;

- cultivating traditional music during religious holidays and family celebrations (Christmas, Easter, family patron saint - slava, etc.);

- encouraging children to attend elective curricular and extracurricular activities that honor and celebrate traditional values;

- including children into recreational activities (folk ensembles, ethno workshops, etc.) that cultivate traditional music;

- attending concerts of traditional music and similar events;

- visiting ethnographic museums, libraries (heritage departments), ethno villages and other institutions that aim to preserve national cultural heritage.

The key role of family involves building elements of folk tradition that will be later upgraded and adopted through different subject areas in school.

The cooperation between school and family helps to familiarize children with the musical tradition of their country, and thus with the criteria for identifying authentic folk music and art in general (Ivanović, 2007).

Moreover, the Rulebook on the Curricula (Teaching and Learning Plan) proposes that parents should be involved in the implementation of the content related to folk tradition, because the general opinion is we have little space left "to develop sensitivity toward musical values by learning about folk tradition of our own, and other people's" (Curriculum for the First Cycle of Primary Education, 2006, 90). Among other things, the Strategy for Educational Development in Serbia 2020 specifies that "the cooperation between school and family is not based on partnership", and that in order to overcome this outdated concept, "schools should apply the concept of partnership between school and parents/guardians" (Ibid, 2006, 90). The coordination between school and family will achieve a broader synergistic relationship, which means 

primary school age, International Journal of Cognitive Research in Science, Engineering and Education (IJCRSEE), 8(3), 103-112.

that school and family together can achieve much more than by acting on their own (Zuković, 2012b). The new concept based on partnership between school and family provides the opportunity to design learning and purposefully organize part of students' free time thanks to an early discovery of different interests and abilities of students. Such an approach can reinforce the cultivation of local musical tradition.

Many analysts (Amato, 2001; Berk, 2005; Kieman, 2003; Nelson, 1993) point out that modern family is undergoing a crisis, which often results in increased divorce and separation rates, and such events put pressure on children, exposing them to constant stress and forcing them to adapt to new circumstances in order to overcome the crisis (As cited in: Vulfolk et al. 2014, 174-175). All socio-economic problems are inevitably reflected on family, which causes the value system to collapse, or rather to become vague and undefined, confusing parents and complicating their educational efforts. The cause of this situation lies in "everyday stress and uncertainty arising from socio-economic circumstances in which society has been caught at the turn of the century" (Nikolić, 2012, 22). If we view a child as a social being who "constantly interacts with his environment, and actively participates in the construction of his knowledge - discovering new meanings, developing new mental structures and accepting the values of the culture he/she is a part of' (Zuković, 2012a, 149), then it is crucial to provide support to children at all institutional levels.

Therefore, it is important to point out the outlook (DeFrain, 1999, as cited in: Zuković, 2012a) according to which the strategy for strengthening modern family should exist and should be carried out by different partakers in social life: teachers (...), politicians (...), media, counselors, social workers and volunteers, as well as by every family member who seeks ways and opportunities to create healthy family relations imbued primarily with love (Zuković, 2012a). A family thus empowered and working in partnership with school provides far better opportunities for the cultivation of traditional folk music, and consequently raises awareness of the importance of musical tradition in the life of every individual.

The aim of this paper is to draw attention to the importance and role of family in the cultivation, and thus in the preservation of traditional folk music, because learning about this topic "begins in the family, and continues in an organized, systematic, planned and continuous way in school" (Calić, 2011, 253). The role of school is to establish good cooperation and partnership with parents/guardians, and to further encourage the nurturing of musical tradition in the family.

Pedagogical research (Nikolić, 2012) indicates that it is necessary to cultivate the pedagogical culture of parents so as to raise their awareness of the responsibility and importance of good upbringing. School and family are in constant interaction and exchange with the environment as complex, living systems which intersect and intertwine through their relationship with the child (Zuković, 2012a). It should be noted that there are numerous studies (Epstein and Sanders, 2002; Milošević, 2002) which analyze the mutual relationship between family and the school system, dealing primarily with the influence of family situation on the child's behavior and their academic achievement. For this reason, we wanted to examine the role of family in the cultivation of musical tradition at junior primary school age. We tried to obtain teachers' opinions on whether family encourages learning about traditional folk music, and if such encouragements are reflected on the realization of formal music education. We also wanted to learn if traditional music is played in the family (in contrast with classical, pop and commercial music). And finally, we wanted to examine the contribution of students' families in music education, i.e. teachers' efforts toward the delivery of content related to traditional folk music in junior grades of primary school with regard to other out-of-school factors.

\section{Materials and Methods}

Research aim. The aim of this survey was to estimate whether family motivates students to learn more about traditional music in music classes at junior primary school age, and the extent to which musical tradition is cultivated in the family by means of listening to traditional folk music, and finally, to determine the influence of family (in relation to other factors) when it comes to the adoption of content related to traditional music.

Research instruments. We designed two questionnaires for the purposes of this survey, one for class teachers (classified by years of service), and the other for students of the fourth grade of primary school (classified by gender and academic achievement). Questionnaire for teachers contained questions for the purpose of establishing teachers' opinions on whether family stimulates learning about music folk tradition and how much that encouragement is reflected in the process of conducting music lessons. Questionnaire for students contained questions aiming to examine the attitude of students on how much is tradional music listened to within family and how much family, in comparison to other out of school factors, contributes to learning folk music tradition. Questionnaires were created by the authors of this work. The 

103-112.

research was anonymous, both for teachers and students. The value of Cronbah Alpha coefficient, for teachers' questionnaire $(0,0897)$ and for students' questionnaire $(0,0898)$, indicates a good reliability of both instruments and justifies their acceptability.

Research sample and techniques. The survey was carried out on a sample of 597 respondents, i.e. students of the fourth grade of primary schools in Užice and Kraljevo, as well as 196 teachers (random selection) who work in primary schools in Užice and Kraljevo. Independent variables for the student sample included student gender and academic achievement, whereas the independent variable for the teacher sample involved professional experience (less than 10 years, 10-20, 20-30, over 30 years).

The research was based on a descriptive research method, and the data were collected using a survey technique.

Statistical data processing was based on the IBM SPSS 20 software package, statistical description and inference. We used a chi-square test to determine the statistical significance in students' opinions.

\section{Results}

\section{Family as an Empowerment Resource Helping School in Its Effort to Improve Student Knowledge of Traditional Folk Music}

The research was aimed at identifying and analyzing the influence of family as perceived by teachers on the existence and sensitivity of children of junior primary school age to traditional music. We were primarily interested in the teachers' observations of the extent to which family encourages learning about traditional music in junior grades of primary school.

Table 1

Assessment of the motivational influence of family on students with regard to adoption of content related to traditional folk music

\begin{tabular}{lcc}
\hline & Frequency & Percent \\
\hline Supportive & 137 & 69,90 \\
Insufficiently supportive & 46 & 23,47 \\
Unsupportive & 13 & 6,63 \\
In total: & 196 & 100 \\
\hline
\end{tabular}

Results show (Table 1) that the majority of 196 teachers-respondents participating in the research agrees that introducing students to musical tradition within their family improves their motivation for learning similar content in music education classes (137 or $69,90 \%)$.

Table 2

Assessment of the motivational influence of family on students aimed at adopting content related to traditional folk music with regard to teachers' professional experience

\begin{tabular}{|c|c|c|c|c|c|c|c|c|}
\hline Years of service & \multicolumn{2}{|c|}{ Supportive } & \multicolumn{2}{|c|}{$\begin{array}{l}\text { Insufficiently } \\
\text { supportive }\end{array}$} & \multicolumn{2}{|c|}{ Unsupportive } & \multicolumn{2}{|c|}{ In total: } \\
\hline Less than 10 years & 27 & $65.85 \%$ & 11 & $26.83 \%$ & 3 & $7.32 \%$ & 41 & $100,00 \%$ \\
\hline $10-20$ years & 48 & $69,57 \%$ & 16 & $23,19 \%$ & 5 & $7,25 \%$ & 69 & $100,00 \%$ \\
\hline $20-30$ years & 37 & $68,52 \%$ & 14 & $25,93 \%$ & 3 & $5,56 \%$ & 54 & $100,00 \%$ \\
\hline Over 30 years & 25 & $78,13 \%$ & 5 & $15,63 \%$ & 2 & $6,25 \%$ & 32 & $100,00 \%$ \\
\hline In total: & 137 & $69,90 \%$ & 46 & $23,47 \%$ & 13 & $6,63 \%$ & 196 & $100,00 \%$ \\
\hline
\end{tabular}

If we analyze respondents' opinions with regard to their professional experience, we can see that the largest number of teachers who positively asses motivation from the family are also the most professionally experienced (over 30 years of service), in other words, they believe that family is a significant motivating factor and a good incentive for learning about musical tradition. Least experienced respondents (less than 
Ćalić, M., \& Đurđanović, M. (2020). Family and its role in the cultivation and preservation of traditional folk music at junior primary school age, International Journal of Cognitive Research in Science, Engineering and Education (IJCRSEE), 8(3), 103-112.

10 years of service) expressed a negative attitude toward the same issue. The differences observed were not statistically significant $\left(\chi^{2}=1,769, d f=6, p=0,9397\right)$.

We had in mind that the new age and modern technologies reinforce content which, in a way, suppresses and changes the priorities in the assessment of music content in education, and diminishes the role of both family and school. Therefore, we wanted to ask students what kind of music is played within their family environment on different media. (Table 3).

We wanted to learn what kind of music is played, and therefore cultivated in students' families

Table 3

Music preferences in students' families with regard to student gender

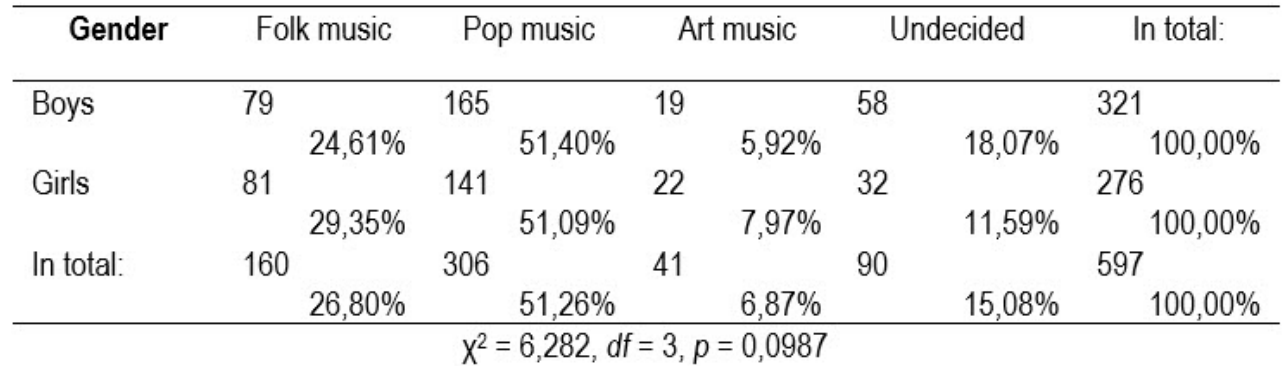

Most students (51\%) listed pop music as the favorite music genre played in their family. 90 students, or $15,08 \%$ were undecided, 160 or $26,80 \%$ prefer folk music, whereas 41 or $6,87 \%$ named art music as the favorite music genre of their family. We observed small differences in the opinions in relation to student gender. A slightly higher percent of boys, 58 or $18,07 \%$ classified themselves as undecided when it comes to a preferred music genre of their family in contrast to 32 or $11,59 \%$ girls who share this opinion.

Testing the statistical significance of differences in respondents' opinions with regard to the preferred music genre in their family with a chi-test square, we obtained the following results: $\chi^{2}=6,282$ for $\mathrm{df}=4$, which means the difference is not statistically significant.

Family should significantly contribute to the cultivation and adoption of traditional folk music by encouraging children to listen to this music genre. Therefore, we wanted to learn what is the preferred music genre in students' families with regard to student academic achievement (Table 4).

Table 4

Student preferences toward folk music with regard to academic achievement

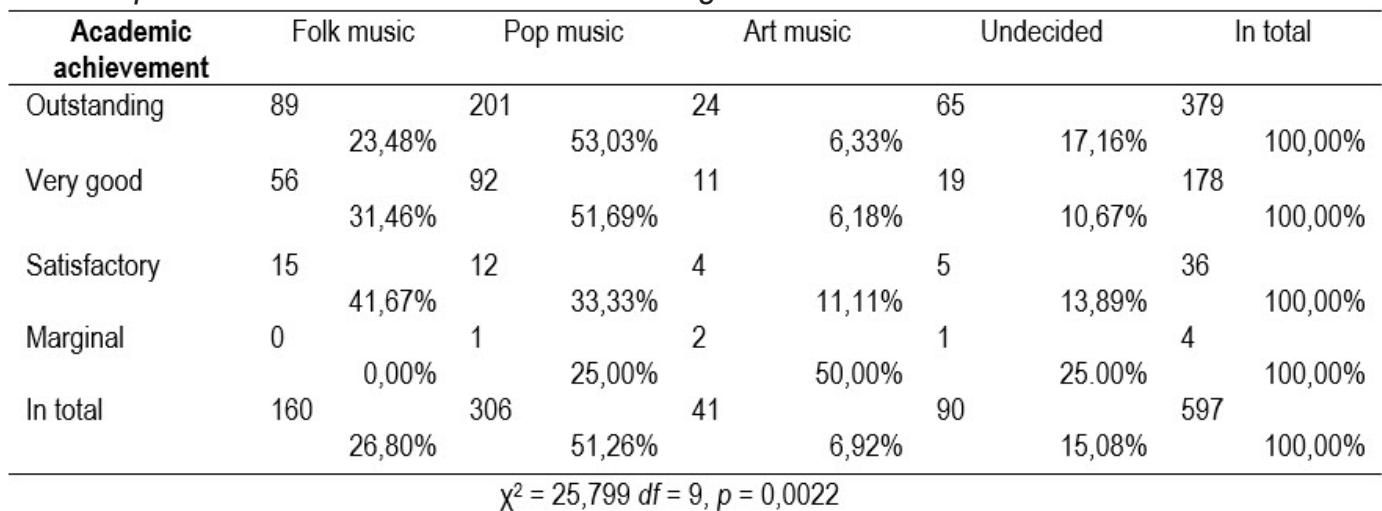

The data in Table 5 show that there are differences in respondents' answers in relation to the independent variable - student academic achievement. When it comes to the preferred music genre within their family, students whose academic achievement was estimated as outstanding responded that it is primarily pop music (201 or $53,03 \%$ ). 65 or $17,16 \%$ of the respondents were undecided. Based on the respondents' preferences, i.e. their attitude toward the music genre preferred in their family, 89 (or 23,48\%) opted for folk music, and 24 (or 6,33\%) opted for art music. Respondents with very good academic achievement also prefer pop music (92 or $51,69 \%$ ), whereas 56 or $31,46 \%$ of students from the same category opted for folk music, in contrast to students with outstanding academic achievement who settled on undecided when it comes to other music genres played in their family. The smallest percent of respondents chose undecided as their attitude (19 or 10,67\%). There is also a difference in the category of respondents with satisfactory academic achievement in relation to other categories of respondents, 
because their preferred music genre is folk music ( 15 or $41,67 \%$ ), which is not the case in the outstanding and very good achievement category.

Testing the statistical significance of differences in respondents' opinions about the preferred music genre of their family with regard to student academic achievement as the independent variable with a chisquare test, we obtained the following results: $\chi^{2}=25,799$ with $\mathrm{df}=9$ degrees of freedom, which means the difference is not statistically significant.

Results of the analysis confirm that traditional folk music (TFM) is insufficiently present in respondents' families.

\section{The Role of Family in the Adoption of Traditional Music in School}

Research shows that students recognize family as "an institution that preserves traditional values", and which is also an indisputably important factor in the cultivation and preservation of traditional music, as well as in familiarizing children with it (Ćalić and Grkić, 2013, 301). Starting from the fact that the cooperation between family and school plays a significant role in introducing one to the musical identity of their country, and thus helps them adopt criteria for recognizing authentic folk music, the second research task was aimed at determining the role of family with regard to other factors that contribute to the adoption of traditional folk music in school (Table 5).

Table 5

Teachers opinions' on the role of family in adoption and cultivation of traditional folk music with regard to their professional qualifications

\begin{tabular}{|c|c|c|c|c|c|c|c|c|c|c|}
\hline $\begin{array}{l}\text { Professional } \\
\text { qualifications }\end{array}$ & & chool & & Family & & Peers & & ledia & & total \\
\hline \multirow{2}{*}{ University degree } & 18 & & 9 & & 32 & & 5 & & 64 & \\
\hline & & $28,12 \%$ & & $14,06 \%$ & & $50,00 \%$ & & $7,81 \%$ & & $100,00 \%$ \\
\hline College/applied degree & 38 & $2878 \%$ & 24 & $1818 \%$ & 62 & $44,49 \%$ & 8 & $606 \%$ & 132 & $10000 \%$ \\
\hline In total & 56 & $28,57 \%$ & 33 & $16,84 \%$ & 94 & $47,96 \%$ & 13 & $6,63 \%$ & 196 & $100,00 \%$ \\
\hline
\end{tabular}

$X^{2}=0,723 d f=3, p=0,8677$

Looking at Table 5, we can see that teachers believe peers (47,96\%) are the most influential factor contributing to the adoption and cultivation of traditional music. The second most influential factor in the adoption of traditional music is school (56 or $28,57 \%$ respondents), whereas 33 (or $16,84 \%$ ) believe family is the decisive factor when it comes to the adoption and cultivation of traditional music. Respondents do not recognize the media as a factor of importance for the cultivation of traditional music. Survey results show that respondents' opinions only slightly differ with regard to their professional qualifications, which was additionally confirmed with a chi-square test. In other words, differences in opinions are not statistically significant, because $\chi^{2}=0,723$ with $\mathrm{df}=3$.

We also wanted to examine if there are any differences in answers to the question - what is the role of other factors, beside family, in the adoption of traditional music in school - in relation to teachers' professional experience (Table 6).

Table 6

Role of family among other factors in the adoption and cultivation of traditional music with regard to teachers' professional experience

\begin{tabular}{|c|c|c|c|c|c|c|c|c|c|c|}
\hline Years of service & & School & & Family & & Peers & & Media & & In total: \\
\hline $\begin{array}{l}\text { Less than } 10 \\
\text { years }\end{array}$ & 9 & $21,95 \%$ & 6 & $14,63 \%$ & 23 & $56,10 \%$ & 3 & $7,32 \%$ & 41 & $100,00 \%$ \\
\hline $10-20$ years & 23 & $23,34 \%$ & 7 & $10,14 \%$ & 33 & $47,82 \%$ & 6 & $8,70 \%$ & 69 & $100,00 \%$ \\
\hline $20-30$ years & 14 & $25,93 \%$ & 11 & $20,37 \%$ & 27 & $50,00 \%$ & 2 & $3,70 \%$ & 54 & $100,00 \%$ \\
\hline Over 30 years & 10 & $31,24 \%$ & 9 & $28,13 \%$ & 11 & $34,38 \%$ & 2 & $6,25 \%$ & 32 & $100,00 \%$ \\
\hline In total: & 56 & $28,57 \%$ & 33 & $16,84 \%$ & 94 & $47,96 \%$ & 13 & $6,63 \%$ & 196 & $6,63 \%$ \\
\hline
\end{tabular}


Looking at Table 6, we can see that family is gaining in importance as a factor relevant for the cultivation and adoption of traditional folk music as the teacher's professional experience increases. Teachers with most extensive professional experience (over 30 years) share the opinion that family, school and peers play an equally important role when it comes to the adoption and cultivation of traditional folk music. Respondents with less experience (under 30 years of service) believe peers are the decisive factor (around 50\%) in the adoption of this content. This group of respondents does not recognize the media as a factor of importance in the cultivation of traditional music.

By calculating the statistical significance of differences in teachers' opinions on the role of family and other factors in the adoption and cultivation of traditional folk music with regard to their professional experience, we can conclude that the difference is not statistically significant, given that the chi-square test showed $\chi^{2}=9,187$ with $\mathrm{df}=9$.

\section{Discussion and Conclusion}

Results of the survey have confirmed that family is an insufficiently utilized resource which can significantly enrich music education in terms of content, as well as other subjects that include similar content, and help in the development of a generally positive attitude of students toward traditional music, and which directly shapes their musical taste and preferences for this music genre.

When it comes to teachers who participated in the survey $(69,90 \%)$ believe that traditional music is sufficiently present in the family. However, it is very significant that $30,00 \%$ of the teachers-respondents believe that traditional values are cultivated insufficiently $(23,47 \%)$, or not at all $(6,63 \%)$ within the family.

Students responded that the most popular music genre in their family environment is pop music $(51,26 \%)$, followed by folk music $(26,80 \%)$, and we also identified a statistically significant difference between students' opinions about the preferred music genre of their family with regard to their academic achievement.

Factors that favorably influence teachers' work on familiarizing their students with traditional music include peers $(47,96 \%$ respondents), school $(28,57 \%)$, and family $(16,18 \%)$. Teachers with less professional experience do not perceive, and consequently, do not involve parents/guardians into the adoption of content related to traditional folk music, whereas teachers with over 30 years of service think that family is an equally important factor as school and peers (mostly members of folk ensembles where they learn traditional dances and songs), and together they greatly improve the realization of content related to traditional music in music education at junior primary school age.

School has a significant role in the cultivation and preservation of traditional music and culture, because it introduces students to this content in an organized and systematic manner. Music education classes provide plenty of topics referring to folk tradition, and as such, provide a good basis for getting to know it. However, we should not ignore the fact that the role of the teacher in the systematic and gradual introduction of traditional music of one's own and other countries into students' lives, is crucial. Teachers should strive to utilize this content in the best possible way, to motivate and engage students, to make the content relatable, to encourage students to join extracurricular activities, and to motivate parents as well, thus increasing the role of family in the cultivation and preservation of traditional music in school.

\section{Acknowledgments}

The paper is the part of the project of Niš Branch of the Serbian Academy of Sciences and Arts (SASA): 0-10-17 "The Music Heritage of Southeast Serbia, Contemporary Creativity and the Formation of Taste".

\section{Conflict of interests}

The authors declare no conflict of interest.

\section{References}

Amato, P. R. (2001). Children of divorce in the 1990s: An update of the Amato and Keith (1991) meta-analysis. Journal of Family Psychology, 15(3), 355-370. https://doi.org/10.1037/0893-3200.15.3.355

Berk, L. E., \& Meyers, A. B. (1996). Infants, children, and adolescents. Boston: Allyn and Bacon.

Bogunović, B. (2008). Muzički talenat i uspešnost [Musical talent and successfulness]. Beograd: Institut za pedagoška istraživanja. 
Ćalić, M., \& Đurđanović, M. (2020). Family and its role in the cultivation and preservation of traditional folk music at junior primary school age, International Journal of Cognitive Research in Science, Engineering and Education (IJCRSEE), 8(3), 103-112.

DeFrain, J. (1999). Strong Families around the World, Family Matters, No.53, 6-13. Retrieved from http://citeseerx.ist.psu.edu/ viewdoc/download?doi=10.1.1.460.8819\&rep=rep1\&type=pdf

Dević, D. (2001). Antologija srpskih i crnogorskih narodnih pesama s melodijama [Anthology of Serbian and Montenegrin folk songs and their tunes]. Beograd: Karić fondacija.

Deletić, Z. (2013). Tradition as a Historical Source. In: V. Milisavljević (Ed.), Science and Tradition: Philosophical Sciences. Conference Proceedings, Book 7. Vol. 2/1 (17-33). Pale: Faculty of Philosophy [Tradicija kao istorijski izvor. U V. Milisavljević (ur.), Nauka i tradicija: filozofske nauke. Zbornik radova sa naučnog skupa, knj. 7, tom 2/1 (17-33)]. Pale: Filozofski fakultet.

Epstein, L. J. \& Sanders, M. G. (2002). Family, School, and Community Partnerships. In: M. N. Bornstein (Ed.) Handbook of Parenting, 5, 407-437. London: Nacional Institute of Child Healt and Human Development.

Fracile, N. (1987). Vokalni muzički folklor Srba i Rumuna u Vojvodini: komparativna proučavanja [Traditional Choral Music of Serbia and Romania in Vojvodina: comparative studies]. Matica srpska.

Golemović, D. (1998). Narodna muzika Jugoslavije [Folk Music of Yugoslavia]. Knjažvac: Nota.

Grandić, R. (2007). Prilozi porodičnoj pedagogiji [Innovations in Family Pedagogy]. Novi Sad: Savez pedagoških društava Vojvodine.

Ivanović, N. (2007). Metodika opšteg muzičkog obrazovanja za osnovnu školu [Teaching Methodology of Primary Music Education]. Beograd: Zavod za udžbenike.

Kiernan, K. (2003). Cohabitation and divorce across nations and generations (CASE Paper 65). London: Centre for Analysis of Social Exclusion.

Kostović, S. (2005). Vaspitni stil nastavnika [Teaching Style of Teachers]. Novi Sad: Savez pedagoških društava Vojvodine.

Krysan, M., Moore, A. K. \& Zill, N. (1990). Resarch on Successful Families.

Levitin, D. J. (2011). Muzika i mozak, Zašto volimo muziku [Music and the Brain, Why Do We Love Music]. Novi Sad: Psihopolis institut.

Ljubinković, N. (1976). Usmeno dečje stvaralaštvo [Oral Children's Creativity]. Zbornik radova: Negovanje izbornog folklora u radu sa decom, Beograd: Savet za vaspitanje i brigu o deci SR Srbije, 53-58.

Manić, I. (2016). Porodične vrednosti mladih u Srbiji [Family Values of the Young in Serbia]. Sinteze, 5(9), 1-14. https://doi. org/10.5937/sinteze0-10759

Milanović, M. \& Anđelković, B. (2013). Sreća i porodice sa decom u Srbiji. Belgrade: Public Policy research Center, UNICEF and Hemofarm Foundation [Happiness and Families with Children in Serbia]. Beograd: Centar za istraživanje javnih politika, UNICEF i Hemofarm fondacija. https://www.unicef.org/serbia/StudijaoSreci-Integralno.pdf

Milošević, N. M. (2002). Effects of the family-school cooperation on student social behavior and academic achievement. Zbornik Instituta za pedagoska istrazivanja, (34), 193-212. https://doi.org/10.2298/ZIPI0204193M

Nelson, G. (1993). Risk, resistance, and self-esteem: A longitudinal study of elementary school-aged children from mother custody and two-parent families. Journal of divorce \& remarriage, 19(1-2), 99-120. https://doi.org/10.1300/ J087v19n01 06

Nikolić, R. (2012). Educational practices in families in the parents' opinion. Zbornik radova Učiteljskog fakulteta, Užice, (14), 21-32. Retrieved from https://scindeks.ceon.rs/article.aspx?artid=1450-67181214021N

Nikšić, N. (2016). Metodička funkcija pesama novopazarskog kraja u nastavi elementarne muzičke pismenosti mlađỉh razreda osnovne škole [Methodological function of Novi Pazar Area Songs in Teaching Music Literacy at Junior Grades of Primary School]. Doctoral Thesis. Beograd: Univerzitet u Beogradu, Učiteljski fakultet. Retrieved from http://nardus. mpn.gov.rs/bitstream/id/19055/Disertacija.pdf

Nešić, V. (2003). Muzika, čovek i društtvo [Music, Man and Society]. Niš: Filozofski fakultet.

Nešić, V., Nešić, M., Milićević, N. \& Todorović, J. (2006). Porodica i muzička iskustva učenika osnovnih škola u Nišu [Family and music experience of the pupils in elementary schools in Niš], Godišnjak za psihologiju,4(4-5), 127-142. Retrieved from http://www.psihologijanis.rs/arhiva-godisnjak/godisnjak-2005-2006/Godisnjak-Vol-4No-4-5-\%282005-2006\%29-127-142.pdf

Olson, D. H. (2000). Circumplex model of marital and family systems. Journal of family therapy, 22(2), 144-167. https://doi. org/10.1111/1467-6427.00144

Pavlović, B. (2013). Tradicionalno narodno muzičko stvaralaštvo Kosova i Metohije u nastavi muzike: priručnik za učitelje i nastavnike muzičke kulture u osnovnoj školi TTraditional Folk Music of Kosovo and Metohija in Music Education: Handbook for Teachers of Music Education in Primary School]. Leposavić: Učiteljski fakultet u Prizrenu - Leposavić.

Pavlović, B. \& Cicović Sarajlić, D. (2013). Obrada narodnog muzičkog stvaralaštva u mlađim razredima osnovne škole po modelu integrativne nastave [Approach to Folk Music in Junior Grades of Primary School (Model of Integrative Model)], Zbornik radova Učiteljskog fakulteta (15), 275-290. http://scindeks.ceon.rs/article.aspx?artid=1450-67181315275P

Pravilnik o planu nastave i učenja za prvi ciklus osnovnog obrazovanja i vaspitanja i programu nastave i učenja za prvi razred osnovnog obrazovanja i vaspitanja, (2017), Prosvetni glasnik, Službeni glasnik Republike Srbije, 10/2017 [Rulebook on the Curricula (Teaching and Learning Plan) for the First Cycle of Primary Education and the Curriculum (Teaching and Learning Plan) for the First Grade of Primary School, (2017), Educational Gazette, Official Gazette of the Republic of Serbia, 10/2017].

Pravilnik o programu nastave i učenja za drugi razred osnovnog obrazovanja i vaspitanja, (2018), Prosvetni glasnik, Službeni glasnik Republike Srbije, 16/2018 [Rulebook on the Curricula (Teaching and Learning Plan) for the Second Grade of Primary School,(2018), Educational Gazette, Official Gazette of the Republic of Serbia, 16/2018].

Pravilnik o nastavom planu za prvi, drugi, treći i četvrti razred i nastavom programu za treći razred osnovnog obrazovanja i vaspitanja (2006), Prosvetni glasnik, Službeni glasnik Republike Srbije, 1/05, 15/06, 2/08, 2/10, 3/11 [Rulebook on the Curricula (Teaching and Learning Plan) for the First, Second, Third and Fourth Grade of Primary School (2006), Educational Gazette, Official Gazette of the Republic of Serbia, 1/05, 15/06, 2/08, 2/10, 3/11].

Radoš, K. (2010). Psihologija muzike [Psychology of Music]. Beograd: Zavod za udženike.

Vidulin, S. \& Martinović, V. (2015). Umjetnička glazba i oblikovanje kulturnoga identiteta učenika [Art Music and and How to Shape Students' Cultural Identity]. Školski vjesnik, 64(4), 573-588. Retrieved from https://hrcak.srce.hr/153129

Vulfolk, A., Hjuz, M. \& Volkap, V. (2014). Psychology in Education I, translated from English by: Vicanović, M. [Psihologija u 
Ćalić, M., \& Đurđanović, M. (2020). Family and its role in the cultivation and preservation of traditional folk music at junior primary school age, International Journal of Cognitive Research in Science, Engineering and Education (IJCRSEE), 8(3), 103-112.

obrazovanju I, prevod sa engleskog: Vicanović, M.] Beograd: Clio.

Zuković, S. (2009). Funkcionalnost savremene porodice i verska nastava kao resurs njenog osnaživanja [Functionality of modern family and religious education as a resource for its empowerment], Pedagoška stvarnost,55(1-2), 33-47.

Zuković, S. (2012a). Porodica kao sistem - funkcionalnost i resusri osnaživanja [Family as a system - functionality and empowerment resources]. Novi Sad: Pedagoško društvo Vojvodine.

Zuković, S. (2012b). The Relationship between Family and School: from Cooperation to Partnership [Odnos između porodice i škole: od saradnje ka partnerstvu. In: O. Gajić (Ed.) (2012). Kvalitet obrazovnog sistema Srbije u evropskoj perspektivi, Zbornik radova/knjiga 2 (219-230). Novi Sad: Univerzitet u Novom Sadu, Filozofski fakultet. Retrieved from http:// digitalna.ff.uns.ac.rs/sadrzaj/2012/978-86-6065-134-3

Čokorilo, R. (2013). Tradicionalni obrasci i savremeni izazovi porodičnog vaspitanja [Traditional Child-Rearing Patterns and Challenges of Modern Upbringing]. In: V. Milisavljević (Ed.) Conference Proceedings Science and Tradition [Naučni skup Nauka i tradicija], tom 2/1. Pale: Univerzitet u Istočnom Sarajevu, Filozofski fakultet, 515-541.

Ćalić, M. (2011). Narodna tradicija u nastavnim sadržajima mlađih razreda osnovne škole [National tradition cross-curricular links in classes in first four years of primary education], Zbornik radova Učiteljskog fakulteta (13), 245-256. Retrieved from https://scindeks.ceon.rs/article.aspx?artid=1450-67181113245C

Ćalić, M. \& Đurđanović, M. (2016). Zastupljenost narodne tradicije u udžbenicima za muzičku kulturu u prvom razredu osnovne škole [Presence of Traditional Music in Music Education Textbooks for the First Grade of Primary School.]. In: A. Pešikan (Ed.). Conference Proceedings Teaching and Learning - Textbook as an Instrument of Teaching and Learning [Naučni skup Nastava i učenje - Udžbenik u funkciji nastave i učenja], 463-476. Retrieved from https://www.pfu.kg.ac. rs/files/Fakultet//zdavastvo/Udzbenik\%20u\%20funkciji\%20nastave\%20i\%20ucenja.pdf

Ćalić, M. \& Grkić, J. (2013). Nastava muzičke kulture i upoznavanje učenika sa sadržajima narodne tradicije u mlađim razredima osnovne škole [Music Education and How to Introduce Students to Traditional Music in Junior Grades of Primary School], Zbornik radova Učiteljskog fakulteta (15), 291-304. http://scindeks.ceon.rs/article.aspx?artid=1450$67181315291 \mathrm{C}$ 